\title{
EFFECT OF PREPUBERTAL INJECTION OF RECOMBINANT BOVINE SOMATOTROPIN (rbST) ON SEMEN CHARACTERISTICS OF RAHMANI RAMS FED DIFFERENT DIETARY ENERGY
}

\author{
Y. M. Hafez ${ }^{1}$, W. M. E. Shakweer ${ }^{2}$, I. M. Awadalla ${ }^{2}$ and H. M. Murad ${ }^{1}$ \\ 1- Department of Animal Production, Faculty of Agriculture, Cairo University, \\ Giza, Egypt, 2- Department of Animal Production, National Research Centre, \\ Dokki, Giza, Egypt
}

\section{SUMMARY}

The objective of this study was to investigate the effect of prepubertal injection of recombinant bovine somatotropin (rbST) on physical and biochemical semen characteristics of Rahmani lambs fed different levels of dietary energy. A total of twelve Rahmani lambs were used in this study. The initial live weights were $30.9 \pm 1.03 \mathrm{~kg}$, (5-6 months old). The lambs were randomly divided into three symmetric experimental groups, the first group $(n=4)$ were treated with Nacl $0.9 \%$ and fed a complete mixed ration containing $72.0 \%$ TDN to cover $100 \%$ of their requirements (Normal Energy, Control). The second and the third groups $(n=4)$ were treated with 100mg rbST/14days, but the second group fed on the same diet of the first group (NE-rbST), while the third group fed a complete mixed ration containing $86.4 \%$ TDN to cover $120 \%$ of their requirements (High Energy, HE-rbST). The lambs were allowed 15 days to adapt to energy diets. The amount of feed was calculated to cover their allowances according to NRC (1985) and modified to cope with body weight changes. After two months from the last dose of rbST, semen samples were collected twice weekly from each ram for nine weeks. Semen volume, sperm motility, abnormalities, live sperm percentage, sperm concentration, sperm total output, total live sperm were recorded. Seminal plasma was separated after centrifugation and stored at $-20^{\circ} \mathrm{C}$ until analysis. Ejaculate volume increased significantly in NE-rbST group compared with HE-rbST, but did not differ significantly from the control. Ejaculate volume did not differ significantly in HE-rbST from the control rams. The $N E$-rbST group had a lower $(P<0.05)$ semen density score than the control, but did not differ significantly compared with HE-rbST group. Sperm concentration increased $(P<0.05)$ in HE-rbST group compared with NE-rbST and the control. There were no significant differences in sperm concentration between NE-rbST and the control groups. Treatment of rbST did not cause any significant effect on sperm mass motility, sperm advanced motility, percentage of live sperm, total live, sperm abnormalities and sperm output in all experimental groups.

Seminal plasma concentration of total protein, globulin, triglycerides, total lipids and activities of $A S T, A L T, A S T / A L T$ ratio and $A / G$ ratio were not changed significantly in all experimental groups. Seminal plasma concentration of albumin decreased $(P<0.05)$ in HE-rbST compared with NE-rbST, but did not differ significantly from the control. Seminal albumin concentration did not differ significantly in NE-rbST compared with the control. Seminal plasma concentration of

Issued by The Egyptian Society of Animal Production 
cholesterol increased $(P<0.05)$ in HE-rbST compared with the control, but did not differ significantly from NE-rbST group. However, seminal plasma cholesterol concentration in NE-rbST group did not differ significantly compared with the control.

Keywords: rbST, rams, semen characteristics, seminal plasma, dietary energy

\section{INTRODUCTION}

There is evidence suggesting that growth hormone (GH) plays an important role in the reproductive process. In the male GH receptors are found in leydig and sertoli cells, vas deference, prostate, ducts epididymis and seminal vesicles (Lobie et al., 1990). Recombinant bovine somatotropin may play roles in controlling spermatogenesis and steroidogensis. Schallenberger et al. (1993) found that the number of spermatozoa and percentage of sperm motility increased in treated-bulls with $\mathrm{rbST}(640 \mathrm{mg} / \mathrm{rbST} / 14$ days) and possibly obtain a greater number of semen doses.

Sauerwein et al. (2000) reported that the ejaculate volume decreased during and after treatment with recombinant bovine somatotropin (rbST) compared with the control. Sperm concentration increased, but the percentage of spermatozoa with acrosomal and other abnormalities was greater in rbST-bulls compared with the control, which reduced after the treatment in the rbST-bulls. During and after rbST treatment, the motility rates increased compared with the control. All bulls allocated to the rbST treatment had a higher concentration of seminal plasma fructose and citrate. The non-return rates (NNR) were equal in the two groups before rbST treatment, but from then on, an increase of NNR was observed in the rbST treated group. EL-Harairy (2000) found that the ejaculate volume, percentage of live sperm, sperm concentration and total sperm output per ejaculate were significantly higher in rbST treated rams compared with the control. The sperm abnormalities were significantly lower in rbST-treated rams compared with the control.

Fourie et al. (2004) investigated the influence of two feeding regimes on scrotal, testicular and semen characteristics for young Dorper rams. The sperm concentration was greater in EM rams $\left(1170.3 \times 10^{6}\right.$ cells $\left./ \mathrm{ml}\right)$ compared with IM rams $\left(731.6 \times 10^{6}\right.$ cells $/ \mathrm{ml})$.

The objective of this study was to investigate the effect of prepubertal injection of recombinant bovine somatotropin (100mg rbST/14 days, 7 injections) on physical and biochemical semen characteristics of Rahmani lambs fed different levels of dietary energy ( normal energy and high energy).

\section{MATERIALS AND METHODS}

This study was carried out at Animal Physiology Lab., Faculty of Agriculture, Cairo University, Giza, Egypt, and laboratories of Animal Production Department, National Research Centre. Dokki, Giza, Egypt during the period from January to September 2004. 


\section{1- Experimental animals}

A total of twelve Rahmani lambs were used in this study. The initial weights were $30.9 \pm 1.03 \mathrm{Kg}$, (5-6 months old). The lambs randomly divided into three symmetric experimental groups. Animals were housed in semishaded yards, Water was free all time.

\section{2- Feeding}

The lambs were divided into three symmetric groups. The first group $(n=4)$ was treated with Nacl $0.9 \%$ and fed a complete mixed ration containing $72.0 \%$ TDN to cover $100 \%$ of their requirements, $14.0 \% \mathrm{CP}$ and $17.7 \% \mathrm{CF}$ (Normal Energy, Control). The second and third groups ( $\mathrm{n}=4$ of each) were treated with $\mathrm{rbST}(100 \mathrm{mg}$ $\mathrm{rbST} / 14$ days, 7 injections), the second group fed on the same diet of the control group (NE-rbST), while the third group fed on diet containing 86.4\% TDN to cover $120 \%$ of their requirements, $13.7 \% \mathrm{CP}$ and $13.7 \% \mathrm{CF}$ (High Energy, HE-rbST), respectively. The ingredients of feeding rations are presented in Table1.

Table 1. Ingredients and chemical analysis (\%) of experimental diets

\begin{tabular}{lcc}
\hline \multirow{2}{*}{ Ingredients (\%) } & \multicolumn{2}{c}{ Experimental diets } \\
\cline { 2 - 3 } & $\begin{array}{c}\text { Normal Energy } \\
\text { (NE) }\end{array}$ & High Energy (HE) \\
\hline Yellow corn & 25 & 40.5 \\
Sunflower cake & 15 & 2 \\
Soya bean meal & 10 & 14 \\
Wheat bran & 10 & 3 \\
Bean straw & 16 & 4 \\
Sugar beet pulp & 17 & 29 \\
Magnapac & 3 & 4.5 \\
Lime stone & 2 & 2 \\
Salt & 1 & 1 \\
Minerals and vitamins & 1 & 1 \\
mixture & 72.3 & 86.4 \\
TDN/ DM & 14.0 & 13.7 \\
CP/ DM & 17.7 & 13.7 \\
CF/ DM & & \\
\hline
\end{tabular}

Protected fat used (Magnapac ${ }^{\circledR}$, Norel S.A., Spain) contains of $84.0 \%$ Brute fat, $9.0 \%$ Calcium, $0 \%$ Protein, $0 \%$ Ash, $3.4 \%$ Humidity and $100 \mathrm{mg} / \mathrm{Kg}$ Antioxidant (BHT), to perform the energy levels of the diet.

The lambs were allowed 15 days to adapt to energy diets. The amount of feed was calculated to cover their allowances according to NRC (1985) and modified to cope with body weight changes. The complete mixed ration was offered in a pellet form twice daily at $8.0 \mathrm{am}$ and $2.0 \mathrm{pm}$.

\section{3- Treatment of rbST}

After the end of the adaptation period, the injection of rbST was started, the rbST treated lambs received $100 \mathrm{mg}$ of somatech $^{\mathrm{TM}}$ bovine somatotropin (sterile sometribove zinc suspension, Austria), 7 injections every two weeks . The rbST was 
given subcutaneously in the prescapular region. Untreated animals were injected with saline solution $(0.9 \% \mathrm{Nacl})$ in the same area following the same regime and the same volume (ml).

\section{4- Semen Samples}

After two months from the last dose of rbST, semen samples were collected twice weekly for each ram for nine weeks (from July to September) by means of an artificial vagina (AV) after precollection stimulation consisting of 3 false mounts and active restrain, the ram is allowed to mount the female. Upon ejaculation, the AV was immediately tilted downward toward the test tube. The semen was drained into the collection tube, which is then removed and placed in water bath maintained at $37^{\circ} \mathrm{C}$. Semen volume, semen motility, abnormalities, live sperm percentage and sperm concentration were recorded. Then, semen samples were centrifuged at 5000 r.p.m. for 10 minutes at $4^{\circ} \mathrm{C}$. The recovered seminal plasma fraction was centrifuged at 10.000 r.p.m. for 15 minutes at $4^{\circ} \mathrm{C}$ and supernatant was stored at $-20^{\circ} \mathrm{C}$ until analysis as described by Taha et al. (2000). Total sperm output for each ejaculate was calculated according to following formula:

Total sperm output/ejac. $\left(\mathbf{x 1 0}^{9}\right)=$ volume $X$ Sperm Concentration $/ \mathrm{ml}$

\section{5- Biochemical Analysis}

Biochemical analysis of seminal plasma was assayed according to the following Table 2.

Table 2. The methods and the kits which were used to quantify the different parameters of seminal plasma

\begin{tabular}{lccc}
\hline \multicolumn{1}{c}{ Parameters } & Method & Company & Reference \\
\hline Total protein & Colorimetric & Stanbio Laboratory(Boerne, & Cannon et. al., \\
& Texas,78202 USA) & (1974) \\
Albumin & Colorimetric & Stanbio Laboratory(Boerne, & Dumas and \\
& Enzymatic- & Texas,78202 USA) & Biggs (1972) \\
Triglycerides & colorimetric & Texas,78202 USA) & Scheletter and \\
& Colorimetric & Biodiagnostic ( Dokk, Giza, & Zollner and \\
Total Lipids & Enzymatic- & Stanbio Laboratory(Boerne, & Kirsch (1962) \\
& colorimetric & Texas,78202 USA) & Stein (1986) \\
Cholesterol & Quimica Clinica Aplicada & Reitman and \\
& Colorimetric & S.A.(Amposta, Spain) & Frankel (1957) \\
& & &
\end{tabular}

\section{6- Statistical Analysis}

Data were analyzed using the general linear model of SAS (1998). Using the following model: -

Where:

$$
Y_{i j}=\mu+T_{i}+E_{i j}
$$

$\mathrm{Y}_{\mathrm{ij}}=$ the observation $\mathrm{ij}$ 
$\mu=$ Overall mean

$\mathrm{T}_{\mathrm{i}}=$ Treatment $(\mathrm{i}=1$, Normal energy and saline $\mathrm{i}=2$, Normal energy and $\operatorname{rbST}$ and $\mathrm{i}=3$, High energy and rbST)

$\mathrm{E}_{\mathrm{ij}}=$ Experimental error associated with $\mathrm{ij}$ observation assumed to be randomally distributed.

Differences between means were tested using (Duncan, 1955). Repeated measurements were adjusting according to Neter et al. (1985).

\section{RESULTS AND DISCUSSION}

\section{1-Semen physical characteristics responses}

Effects of rbST treatment on semen physical characteristics of Rahmani rams are presented in Table (3).

Table 3. Effect of rbST treatment on semen physical characteristics $\left(\mathrm{X}^{-} \pm \mathrm{SE}\right)$ of Rahmani rams fed different dietary energy

\begin{tabular}{|c|c|c|c|}
\hline \multirow{3}{*}{ Parameters } & \multicolumn{3}{|c|}{ Dietary energy levels } \\
\hline & \multicolumn{2}{|c|}{$\mathrm{NE}^{*}$} & $\mathrm{HE}^{* *}$ \\
\hline & Control & $\mathrm{rbST}$ & $\mathrm{rbST}$ \\
\hline Ejaculate volume (ml) & $1 . .{ }^{d c_{1}} \pm 0.04$ & $1.1 \wedge^{\mathrm{cb}} \pm 0.07$ & $.97 \mathrm{~d}_{ \pm 0.05}$ \\
\hline Density (score; 0-5) & $3.80^{\mathrm{a}} \pm 0.11$ & $3.47^{\mathrm{b}} \pm 0.10$ & $3.73^{\mathrm{ab}} \pm 0.09$ \\
\hline Mass motility (score; $0-5$ ) & $£ . \wedge \wedge \pm 0.06$ & $\leq .9 \leqslant \pm 0.03$ & $4.82 \pm 0.09$ \\
\hline Advanced motility (\%) & $79.22^{\mathrm{ab}} \pm 1.51$ & $80.10^{\mathrm{ab}} \pm 1.34$ & $78.06^{\mathrm{b}} \pm 2.38$ \\
\hline Live sperm $(\%)$ & $84.14^{\mathrm{b}} \pm 1.31$ & $84.30^{\mathrm{b}} \pm 1.15$ & $85.82^{\mathrm{ab}} \pm 1.44$ \\
\hline Total abnormalities $(\%)$ & $16.20 \pm 0.99$ & $16.32 \pm 0.98$ & $17.89 \pm 1.04$ \\
\hline Sperm concentration $\left(10^{9} / \mathrm{ml}\right)$ & $320.46^{\mathrm{bc}} \pm 16.43$ & $282.80^{\mathrm{c}} \pm 16.43$ & $380.05^{\mathrm{a}} \pm 17.94$ \\
\hline Sperm output ( $10^{9} /$ ejaculate $)$ & $320.46^{\mathrm{ab}} \pm 28.81$ & $333.70^{\mathrm{ab}} \pm 28.81$ & $364.90^{\mathrm{a}} \pm 31.46$ \\
\hline Total output live ( $10^{9} /$ ejaculate $)$ & $269.63^{\mathrm{ab}} \pm 27.50$ & $281.31^{\mathrm{ab}} \pm 21.16$ & $313.16^{\mathrm{a}} \pm 26.98$ \\
\hline
\end{tabular}

$\mathrm{a}, \mathrm{b}, \mathrm{c} \ldots .$. Means having different superscript letters within the same row differ significantly $(\mathrm{P}<0.05) .{ }^{*} \mathrm{NE}$, Normal dietary energy level as TDN $\%{ }^{* *}$ HE, High dietary energy level as TDN \%

\section{Ejaculate volume ( $\mathrm{ml})$}

Ejaculate volume increased $(\mathrm{P}<0.05)$ by $22.9 \%$ in NE-rbST group compared with HE-rbST group (1.18 vs. $0.96 \mathrm{ml}$, respectively). However, the ejaculate volume increased by $18 \%$ in NE-rbST group, but did not differ significantly compared with the control (1.18 vs. $1.00 \mathrm{ml}$, respectively). These findings are in agreement with ELHarairy (2000) who reported that the treatment by rbST $(100 \mathrm{mg} / 14$ days for five injections) caused significant increase in ejaculate volume of $10.5 \%$ in treated rams compared with the control (0.95 vs. $0.86 \mathrm{ml}$, respectively). Also, Hafez et al. (2005) reported an increase $(\mathrm{P}<0.05)$ in ejaculate volume by $29 \%$ in treated bulls with eight injections of $500 \mathrm{mg}$ bST every 14 days compared with the control $(4.0$ vs. $3.1 \mathrm{ml}$, respectively).

These findings disagree with Sauerwein et al. (2000) who found that the treatment with $640 \mathrm{mg}$ of $\mathrm{rbST}$ each 14days lead to the reduction of ejaculate volume 
during and after treatment by rbST compared with the preceding period before treatment in both the control and rbST treated-bulls.

The ejaculate volume did not differ significantly in HE-rbST rams compared with the control rams. This result was observed in rams by Alvarez et al. (1995) who reported that there were no significant differences in ejaculate volume in merino rams, fed rations with an energy content exceeding that of the standard diet by 15,22 and $30 \%$. Fourie et al. (2004) reported that the means of ejaculated volume was not differ significantly $(1.08$ and $1.1 \mathrm{ml})$ for extensive and intensive managed rams, respectively. EL-Sheshtawy et al. (2004) found that the ejaculate volume did not improved for Baladi goats supplemented with protected fat $(50 \mathrm{~g} / \mathrm{h} /$ day $)$ compared with the control.

This is may be indicate that the treatment of rbST in high energy diet $(120 \%$ TDN) did not affect the ejaculate volume compared with the control. Effect of rbST treatment and dietary energy level on semen physical characteristics of Rahmani rams through the experimental period is shown in Fig. (1).
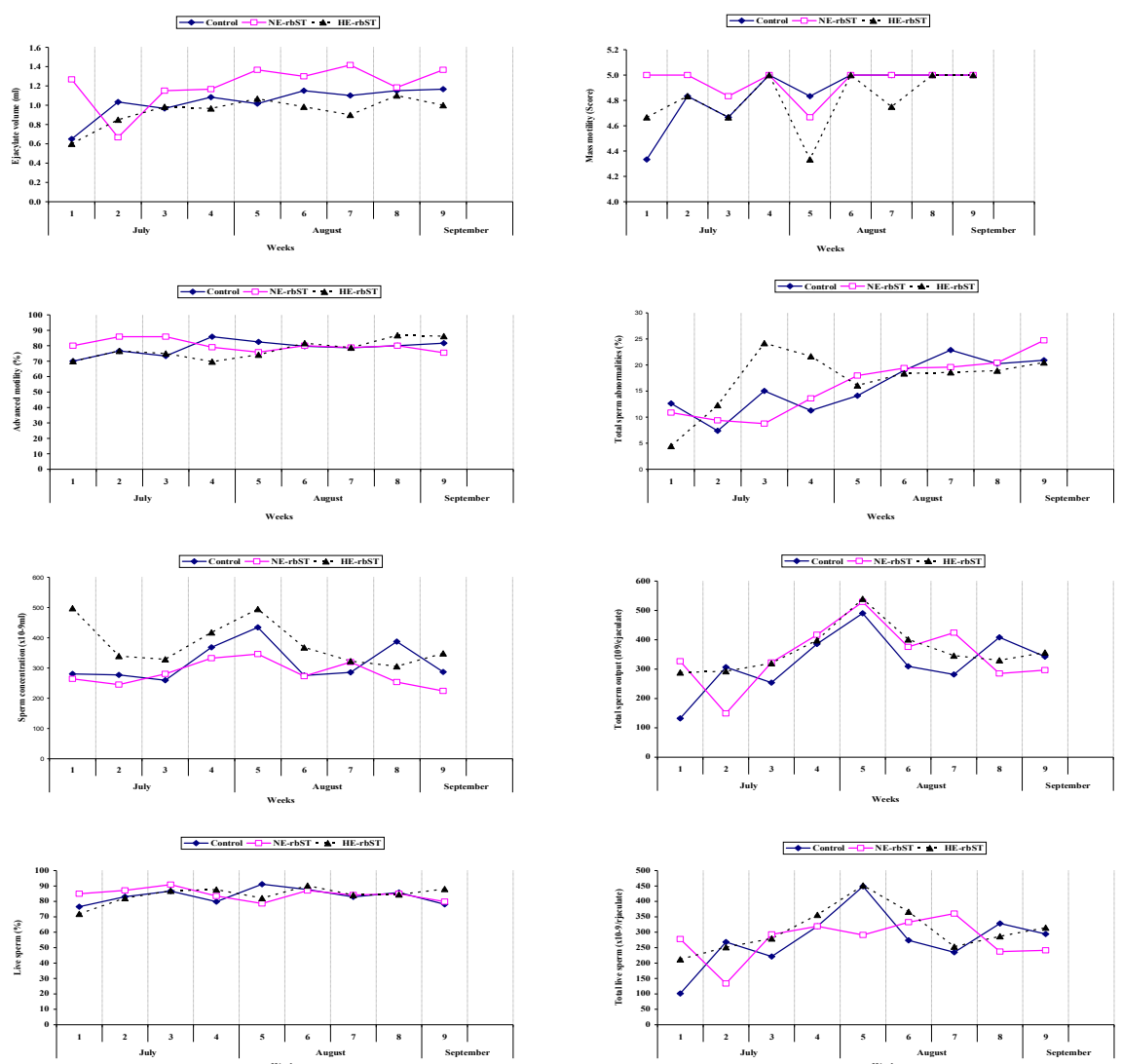

Fig. 1. Effect of rbST treatment and dietary energy levels on semen physical characteristics of Rahmani rams throughout the experimental period 
Sperm Density (Score 0-5)

The NE-rbST group had a lower $(\mathrm{P}<0.05)$ semen density score by $(8.7 \%)$ compared with the control rams. There were no significant differences in semen density score between HE-rbST and NE-rbST rams (3.73 vs. 3.47, respectively). Values of semen density score are ranged from 3.47 to 3.80 . Fourie et al. (2004) found that the semen density of the samples collected from the intensive managed rams varied from watery to milky, while the extensive managed rams varied from milky to creamy.

\section{Mass and Advanced Motility}

Treatment of rbST did not cause any significant effect on sperm mass motility (Score $0-5$ ) or sperm advanced motility (\%) in all experimental groups. However, all groups had high score ranged from 4.88 to 4.94 . Values of advanced sperm motility ranged from 78.06 to $80.10 \%$.

\section{Live Sperm}

There were no significant effect of rbST treatment on the percentage of live sperm and total live sperm $\left(\times 10^{9}\right)$ in all experimental groups. Values of live sperm are ranged from 84.14 to $85.82 \%$. Values of total live sperm concentration ranged from 278.27 to $315.89 \times 10^{9} / \mathrm{ml}$.

\section{Total sperm abnormalities (\%)}

Treatment of rbST did not cause any significant effect on total sperm abnormalities in all experimental groups. The percentage of total sperm abnormalities ranged from 16.20 to $17.89 \%$.

\section{Total sperm output (sperm concentration/ejaculate $\times 10^{9}$ )}

Total sperm output did not differ significantly in all experimental groups. Values of total sperm concentration were ranged from 332.00 to $367.25 \times 10^{9} /$ ejac..

In the present study, mass motility, advanced motility, percentage of live sperm, total live sperm, total sperm abnormalities and total sperm output were not significantly different among experimental groups. In the present study, effect of energy levels on mass motility and advanced motility is in agreement with ElSheshtawy et al. (2002) who found that the supplementation of protected fat $(50 \mathrm{~g} / \mathrm{h} / \mathrm{d}$ Magnapac) did not have any significant effect on semen mass and advanced motility in treated goats compared with the control. In young Dorpar rams Fourie et al. (2004) reported that overall motility and mass motility were significantly higher in extensive managed rams (low energy) compared with the intensively managed rams (high energy) $(80.5 \%$ and 3.3 vs. $50.1 \%$ and 2.3 ), respectively. In Baladi goats ELSheshtawy et al. (2004) found that the dietary protected fat (5\%) did not cause any significant effect on mass and advanced motility compared with the control goats(3.95 and $76.30 \%$ vs. 3.60 and $79.59 \%$ ), respectively. On the other hand, in the present, the effect of rbST on mass motility and advanced motility is in agreement with the result of Sauerwein et al. (2000) in Simmental bulls, who reported that after freezing and thawing semen the sperm motility rates did not differ significantly in treated bulls with rbST (640 mg/14 days) compared with control (64.0 vs. 64.1\%, respectively). In mature rams EL-Harairy (2000) observed that the sperm motility did not significantly differ in Rahmani x Finn rams treated with rbST, 100mg per 14days from the control (83.75 vs. $83.98 \%$, respectively). In Friesian bulls, Hafez et al. 
(2005) reported that bulls treated with $500 \mathrm{mg}$ of rbST every 14 days for eight injections had a higher score of sperm motility compared with the control (3.5 vs. 2.6, respectively).

In the present study, the effect of energy levels on the percentage of live sperm is in agreement with the result of, Fourier et al. (2004) who reported that the live sperm percentage was not significantly changed in extensively managed rams and intensively managed rams (74.6 vs. $68.5 \%$, respectively). It may be possible that the test period of 49 days was not long enough to induce visible changes in sperm viability. Effect of rbST on live sperm percentage in mature rams was reported by EL-Harairy (2000) who found that R x F rams injected with $100 \mathrm{mg} \mathrm{rbST} / 14$ days/ram were significantly $(\mathrm{P}<0.05)$ higher in live sperm percentage than the control rams (80.33 vs. $78.76 \%$, respectively). In bulls, Hafez et al. (2005) reported that treating bulls with $500 \mathrm{mg}$ of rbST every 14 days for eight injections had a higher percentage of live sperm compared with the control (77.2 vs. $69.1 \%$, respectively).

In the present study, effect of energy levels on total sperm abnormalities is in agreement with the result in rams by Fourie et al. (2004) who found that the percentage of abnormal spermatozoa was unsignificantly higher in intensively managed rams (high energy) compared with extensively managed rams (low energy) (17.6 vs. $12.5 \%$, respectively), it may be possible that the test period of 49 days was not long enough to induce visible changes on sperm morphology. However, these results are not in agreement with EL-Sheshtawy et al. (2002) who found that the percentage of abnormal sperm decreased significantly $(\mathrm{P}<0.05)$ in goats supplemented with protected fat $(50 \mathrm{~g} / \mathrm{h} / \mathrm{d}$ Magnapac) compared with the control $(6.1$ vs.13.2\%), respectively. The same authors found the same result in Baladi goats ELSheshtawy et al. (2004) reported that the percentage of abnormalities and acrosomal damage of spermatozoa were reduced significantly $(\mathrm{P}<0.01)$ in goats fed rations containing two sources of protected fat (5\%) compared to the control (4.49 and 4.98 vs. $8.28 \%$, respectively). In rams, EL-Harairy (2000) found that the injection of $\mathrm{R} \mathrm{x}$ $\mathrm{F}$ rams with $100 \mathrm{mg}$ rbST/14days/rams decreased the percentage of abnormal sperm significantly $(\mathrm{P}<0.05)$ compared to control rams $(5.91$ vs. $8.40 \%)$, respectively. In bulls, Hafez et al. (2005) reported that the bulls treated with $500 \mathrm{mg}$ of rbST had a lower percentage of abnormal sperm than the control (16.8vs. $22.5 \%$, respectively).

In the present study, the effect of energy levels on total sperm output is in agreement with Fourier et al. (2004) who found that the total sperm output in the intensively managed rams (high energy) was significantly lower (731.6 vs. $1170.3 \times 10^{6} \mathrm{cells} / \mathrm{ml}$, respectively) compared with extensively managed rams (low energy). Effect of energy levels on total sperm output is in agreement with Sauerwein et al. (2000) who found that total sperm output concentration was higher but not significantly so in bulls treated with $640 \mathrm{mg} \mathrm{rbST} / 14$ days compared with the control during treatment and post-treatment (8.0 and $7.8 \mathrm{vs}$. 6.3 and $6.3 \times 10^{9} /$ ejaculate, respectively). However, the present results are not in agreement with EL-Harairy (2000) and Hafez et al. (2005), whereat in rams EL-Harairy (2000) found that the total sperm output was significantly $(\mathrm{P}<0.05)$ higher in Rahmani $\mathrm{x}$ Finn rams treated with $\mathrm{rbST}(100 \mathrm{mg} / 14 \mathrm{days} / \mathrm{ram})$ compared to the control rams (289.78 vs. $237.63 \times 10^{9} / \mathrm{ml}$, respectively). In bulls, Hafez et al. (2005) reported that the sperm output in treated bulls with rbST was significantly higher compared with the control (5.484 vs. $2.926 \times 10^{9} /$ ejaculate, respectively). 
From these results it may be said that the, effect of rbST on mass motility, advanced motility, percentage of live sperm, total live sperm, total sperm abnormalities and total sperm output is not clear in many ruminant males. The different effect of rbST treatment may be attributed to the differences of the nutritional status, the time from the year and the dose of somatotropin (rbST).

\section{Sperm concentration $\left(10^{9} / \mathrm{ml}\right)$}

In general, effect of high energy level on sperm concentration was clear-cut. Sperm concentration was increased $(\mathrm{P}<0.05)$ in HE-rbST rams by 34.4 and $18.6 \%$ compared with NE-rbST and the control (380.05 vs. 282.80 and $320.46 \times 10^{9} / \mathrm{ml}$, respectively). Sperm concentration in NE-rbST rams was lower by $11.8 \%$, but did not differ significantly compared with the control $(282.80$ and $320.46 \mathrm{x} 109 / \mathrm{ml}$, respectively). The values of sperm concentration ranged from 282.80 to 380.05 $\times 10^{9} / \mathrm{ml}$. Similar result was found in goats by EL-Sheshtawy et al. (2002) who found that sperm concentration was increased significantly $(\mathrm{P}<0.05)$ in goats supplemented with protected fat (50g/h/d Magnapac) compared with the control (3345.0 vs. 2646.7 $\mathrm{x} 10^{6} / \mathrm{ml}$, respectively). In rams, Fourie et al. (2004) found that the linear progression of sperm cells concentration from the extensively managed rams was significantly higher than that of the intensively managed rams. In rams EL-Sheshtawy et al. (2004) reported that the sperm concentration was increased $(\mathrm{P}<0.01)$ in goats fed rations containing protected fat (5\% from two sources) compared to the control (3111.2 and 3034.9 vs. $2462.5 \times 10^{6} / \mathrm{ml}$, respectively).

Sperm concentration in rams of NE-rbST was lower, but did not differ significantly from the control rams $\left(282.8\right.$ and $320.5 \times 10^{9} / \mathrm{ml}$, respectively). This finding id in agreement with Sauerwein et al. (2000) who found that sperm concentration was lower in Simmental bulls treated with $640 \mathrm{mg}$ rbST/14 days during and post-treatment $\left(1.2\right.$ and $\left.1.3 \times 10^{9} / \mathrm{ml}\right)$ compared with the control $(1.4$ and $1.6 \times 10^{9} / \mathrm{ml}$ ), respectively. In mature rams EL-Harairy (2000) reported that $\mathrm{R} \times \mathrm{F}$ rams treated with $100 \mathrm{mg} \mathrm{rbST} / 14$ days did not differ significantly in sperm concentration from the control (298.15 vs. $302.61 \times 10^{6} / \mathrm{ml}$, respectively). On the other hand, the sperm concentration in the present study is not in agreement with the result found in bulls by Hafez et al. (2005) who reported that sperm concentration was a significantly higher in bulls treated with $500 \mathrm{mg} \mathrm{rbST} / 14$ days compared with the control (1.287 vs. $0.890 \times 10^{9} / \mathrm{ml}$, respectively).

\section{2- Seminal plasma characteristics responses}

Table (4) shows the effect of rbST treatment and energy levels on seminal plasma parameters.

In the present study, seminal plasma concentrations of total protein, globulin, triglycerides, total lipids and activities of AST, ALT, AST/ALT ratio A/G ratio were not changed significantly in all experimental groups. Concentration of seminal albumin was significantly higher in NE-rbST compared with HE-rbST, but did not differs significantly compared with the control. At the same time, concentration of seminal albumin did not differ significantly in HE-rbST compared with the control. Seminal plasma concentration of cholesterol increased significantly $(\mathrm{P}<0.05)$ in HErbST compared with the control, but did not differs significantly compared with NErbST rams. However, seminal plasma cholesterol concentration in NE-rbST group did not differ significantly compared with the control. 
The results of the present study are in agreement with the results which obtained in Baladi goats, EL-Sheshtawy et al. (2002) found that the concentration of total protein, albumin and globulin in seminal plasma did not increased significantly in supplemented goats with protected fat $(50 \mathrm{~g} / \mathrm{h} / \mathrm{d}$ Magnapac) compared with the control (10.3, 21.50 and 82.13 vs. 10.2, 19.97 and $82.43 \mathrm{~g} / \mathrm{dl}$, respectively).

Table 4. Effect of rbST treatment on seminal plasma characteristics $\left(\mathrm{X}^{-} \pm \mathrm{SE}\right)$ of Rahmani rams fed different dietary energy

\begin{tabular}{|c|c|c|c|}
\hline \multirow{3}{*}{ Parameters } & \multicolumn{3}{|c|}{ Dietary energy levels } \\
\hline & \multicolumn{2}{|c|}{$\mathbf{N E}^{*}$} & \multirow{2}{*}{$\begin{array}{l}\mathrm{HE}^{* * *} \\
\mathrm{rbST}\end{array}$} \\
\hline & Control & rbST & \\
\hline Total protein $(\mathrm{g} / 100 \mathrm{ml})$ & $6.64 \pm 0.24$ & $6.45 \pm 0.24$ & $6.67 \pm 0.26$ \\
\hline Albumin $(\mathrm{g} / 100 \mathrm{ml})$ & $3.18^{\mathrm{cb}} \pm 0.09$ & $3.37^{\mathrm{ab}} \pm 0.09$ & $3.09^{c} \pm 0.09$ \\
\hline Globulin $(\mathrm{g} / 100 \mathrm{ml})$ & $3.46 \pm 0.23$ & $3.09 \pm 0.23$ & $3.58 \pm 0.25$ \\
\hline $\mathrm{A} / \mathrm{G}$ ratio & $1.15 \pm 0.10$ & $1.19 \pm 0.10$ & $1.19^{\mathrm{a}} \pm 0.11$ \\
\hline Total lipids $(\mathrm{g} / 100 \mathrm{ml})$ & $0.87^{\mathrm{ab}} \pm 0.03$ & $0.92^{\mathrm{a}} \pm 0.03$ & $0.93^{\mathrm{a}} \pm 0.03$ \\
\hline $\begin{array}{l}\text { Triglycerides } \\
(\mathrm{mg} / 100 \mathrm{ml})\end{array}$ & $235.50 \pm 8.36$ & $232.76 \pm 7.33$ & $229.06 \pm 5.16$ \\
\hline Cholesterol (mg/100ml) & $202.20^{c} \pm 6.08$ & $214.47^{\mathrm{cab}} \pm 6.16$ & $222.00^{\mathrm{ab}} \pm 7.00$ \\
\hline $\begin{array}{l}\operatorname{AST}(\mathrm{U} / \mathrm{ml}) \\
\operatorname{ALT}(\mathrm{U} / \mathrm{ml})\end{array}$ & $\begin{array}{l}76.64^{\mathrm{b}} \pm 4.97 \\
64.79^{\mathrm{ab}} \pm 8.10\end{array}$ & $\begin{array}{l}73.75^{\mathrm{b}} \pm 6.12 \\
58.31^{\mathrm{b}} \pm 3.92\end{array}$ & $\begin{array}{c}81.86^{\mathrm{ab}} \pm 7.89 \\
60.21^{\mathrm{b}} \pm 3.74\end{array}$ \\
\hline AST/ALT ratio & $1.40 \pm 0.17$ & $1.33 \pm 0.11$ & $1.41 \pm 0.13$ \\
\hline
\end{tabular}

$\mathrm{a}, \mathrm{b}, \mathrm{c} .$. Means having different superscript letters within the same row differ significantly $(\mathrm{P}<0.05) .{ }^{*} \mathrm{NE}$, Normal dietary energy level as TDN $\%{ }^{* *} \mathrm{HE}$, High dietary energy level as TDN \%

Effect of rbST treatment and dietary energy level on seminal plasma constituents of Rahmani rams thoughout the experimental period is shown in Fig. (2). The total lipids of seminal plasma in the present study are not in agreement with the result reported by EL-Sheshtawy et al. (2002) who found that the total lipids of seminal plasma was increased significantly $(\mathrm{P}<0.05)$ in supplemented goats with protected fat $(50 \mathrm{~g} / \mathrm{h} / \mathrm{d}$ Magnapac) compared with the control (2591.4 vs. $1088.7 \mathrm{mg} / \mathrm{dl})$, respectively. The same authors found the same result in Baladi goats, EL-Sheshtawy et al. (2004) used two sources of protected fat (5\% from each) in goats rations where they found that the total lipids of seminal plasma was increased $(\mathrm{P}<0.05)$ in goats supplemented with protected fat compared with the control (2513.3 and $3289.7 v s$. $1871.6 \mathrm{mg} / \mathrm{dl}$, respectively).

However, EL-Sheshtawy et al. (2002) reported that the cholesterol of the seminal plasma was decreased $(\mathrm{P}<0.05)$ in goats supplemented with protected fat $(50 \mathrm{~g} / \mathrm{h} / \mathrm{d}$ Magnapac) compared with the control (380.0 vs. $730.0 \mathrm{mg} / \mathrm{dl}$, respectively). This result is not in agreement with the result which reported by the same authors in Baladi goats, EL-Sheshtawy et al. (2004) useing two sources of protected fat (5\% from each source) in goat rations, they reported that the cholesterol of the seminal plasma was increased significantly $(\mathrm{P}<0.05)$ in supplemented goats compared with the control ( 730.0 and $749.7 v s .653 .3 \mathrm{mg} / \mathrm{dl}$, respectively). This difference in cholesterol concentration of seminal plasma may be attributed to increasing the 
dietary energy level from $50 \mathrm{~g} / \mathrm{h} / \mathrm{d}$ to $5 \%$ protected fat from goats rations. This result in agreement with the result of our study, on rbST- HE (120\%TDN) showing an increase in seminal cholesterol compared with NE-rbST and with the control rams.
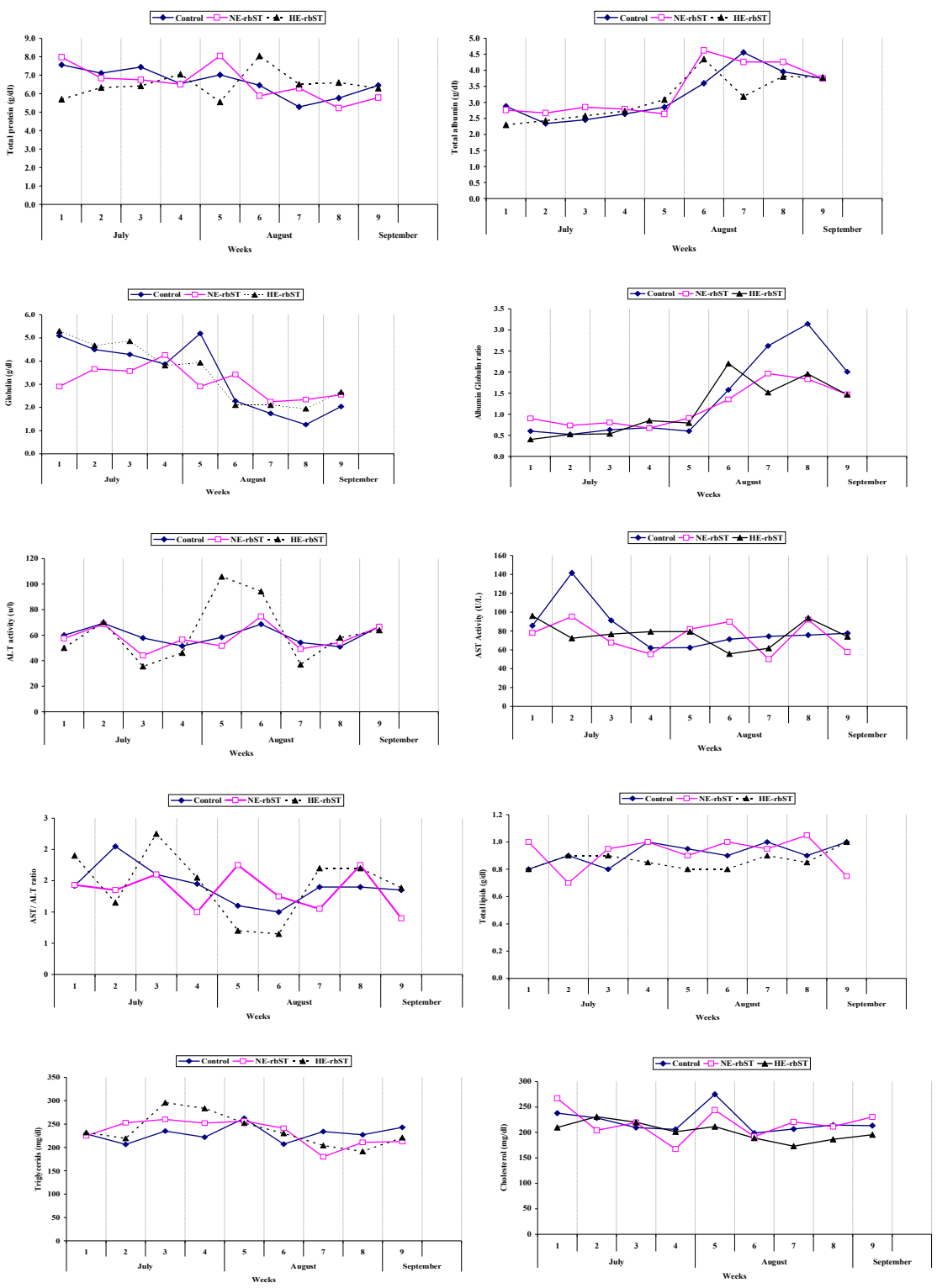

Fig. 2. Effect of rbST treatment and dietary energy level on seminal plasma constituents of Rahmani rams thoughout the experimental period 
Concentration of seminal plasma triglycerides in the study disagree with ELSheshtawy et al. (2002) who found that the concentration triglycerides was increased significantly $(\mathrm{P}<0.05)$ in goats supplemented with protected fat $(50 \mathrm{~g} / \mathrm{h} / \mathrm{d}$ Magnapac $)$ compared with the control (1386.4 vs. $980.0 \mathrm{mg} / \mathrm{dl}$, respectively). Similar result was reported by the same authors EL-Sheshtawy et al. (2004).

Effect of rbST treatment on activity of ALT and AST was reported by Hafez et al. (2005) that the activity of AST in seminal plasma was higher $(\mathrm{P}<0.05)$ in bulls treated with $\mathrm{rbST}$ compared with the control (114.1 vs. $99.0 \mathrm{RFU} / \mathrm{ml}$, respectively). On the other hand, activity of ALT was lower $(\mathrm{P}<0.05)$ in treated bulls compared with the control (33.5 vs. $28.9 \mathrm{RFU} / \mathrm{ml}$, respectively).

Effect of rbST on seminal plasma parameters in the present study was similar to that reported in blood plasma observed in goats and ewes by Sallam et al. (2005) using two different doses of rbST 50 or $100 \mathrm{mg} / 14$ days/ewe for 8 weeks. They reported that the blood plasma concentrations of total protein, albumin and globulin, albumin globulin ratio and activities of AST and ALT did not change significantly in treated-ewes compared with the control. In addition to the concentration of plasma cholesterol was decreased significantly in treated-ewes compared with the control. The same authors found the same results in goats, Sallam et al. (2005) used the same doses of $\mathrm{rbST}$ (50 or $100 \mathrm{mg} \mathrm{rbST} / 14$ days/goat) and fed diets provided $120 \%$ TDN from their requirements (NRC, 1985). In bulls EL-Henawy (2006) found that the concentration of total lipids did not differ significantly in bulls treated with $500 \mathrm{mg} / \mathrm{rbST} / 14$ days compared with the control. From these results it may be said that, the treatments of rbST dose not cause significant effect on seminal plasma parameters in the rams.

\section{CONCLUSION}

Use of rbST possibly improves semen characteristics of Rahmani rams fed normal and high dietary energy.

\section{ACKNOWLEDGEMENT}

The authors would like to thank the National Research Center, Dokki, Giza, Egypt for financing this work throughout the project of "Some nutritional and physiological studies to enhance the productive performance of Baladi Goats under newly reclaimed land condition", Project number 1/34/6. This work has been conducted at Animal Physiology Lab., Faculty of Agriculture, Cairo University and Animal Production Dept., National Research Center.

\section{REFERENCES}

Alvarez, J.L, V. Zaldivar, A. Boado, M. Lannes, A. Tamayo-Aviles and R. Faure, 1995. Influence of the energy and protein levels in rations on the onset of puberty and semen quality in male Holstein. Revista-de-Salud-Animal. 17, 2: 189-200, (Abstract).

Bhosrekar, M. R., P.R. Nisal, J.R. Purohit, A.B. Pande and A.L. Joshi, 1986. Semen quality of crossbred bulls fed three different levels of energy. Indian Journal of Animal Sciences. 56 (2); 214-218. 
Cannon, DC et al., 1974. Clinical Chemistry-Principles and Techniques, $2^{\text {nd }}$ Ed. RJ Henry et al., Eds. Harper \& Row, Hagerstown, MD, pp 411-421.

Dumas B.T. and H.G. Biggs, 1972. In Standard Methods of Clinical Chemistry. Vol. 7. Academic press, New York, p 175.

Duncan D. B., 1955. Multiple ranges and multiple F test. Biometrics, 11:1.

EL-Harairy M.A., 2000. Ram reproductive performance in response to treatment with somatotropin. J. Agric. Sci. Mansoura Univ., 25 (7):3987-3994.

EL-Henawy, M.A., 2006. Effect of gonadotropin like hormones and recombinant growth hormone treatments on semen characteristics of Friesian bulls. Ph.D Thesis, Fac. of Agric, Cairo Univ., Egypt.

EL-Sheshtawy, R. I., W.M. Ahmed, R. I. EL-Kady and H. H. EL-Khadrawy, 2004. Effect of protected fats on some nutritional and reproductive profiles in Baladi Bucks. Egypt. J. Basic Appl. Physiol., 3(1): 163-178.

EL-Sheshtawy, R. I., W. M. Ahmed, E. M. Hanafi and S. I. Shalaby, 2000. Trials for improving reproductive traits of Baladi Bucks using feed additives. Assitut Vet. Med. J. Vol. 46 No.92, 285-298.

Fourie, P.J., L.M. Schwalbach, E.W.C. Neser and C. Van der Westhuizen, 2004. Scrotal, Testicular and semen characteristics of young Dorper rams managed under intensive and extensive condition. Small Ruminant Research 54, 53-59.

Hafez, Y. M., S. A. Fawzy, M. A. EL-Henawy and A. H, Barkawi, 2005. Effect of recombinant bovine somatotropin (rbST) on semen physical characteristics and some biochemical constituents in seminal plasma of Friesian bulls. Egyptian J. Anim. Prod., 42 (2):87-94.

Lobie, P.E., W. Breipohl, J.G. Aragon, M.J. Waters., 1990. Cellular localization of the growth hormone receptor binding protein in the male and female reproductive systems. Endocrinology 126, 2214-2221.

National Research Council, 1985. Nutrient Requirement of sheep. $6^{\text {th }}$ revised ed. National Academy of sciences. Washington, DC.

Neter, J., W. W. Wasserman and M. H. Kestener, 1985. Applied linear statistical methods regression analysis of variance and experimental designed. $2^{\text {nd }}$ ed. Richared D. Irwim, Home wood, Illions 60430 USA.

Reitman, S. and S. Frankel, 1957. Calorimetric determination of AST and ALT activity. Am.J. Clin. Path., 28, 56-63.

Sallam, S.M.A., M.E.A. Nasser and M.I. Yousef, 2005a. Effect of recombinant bovine somatotropin on sheep milk production, composition and some hematoBiochemical components. Egyptian J. Anim. Prod., 42 (1):33-46.

Sallam, S. M.A., M.E.A. Nasser and M.I. Yousef, 2005b. Effect of recombinant bovine somatotropin administration on milk production, composition and some hemato-Biochemical parameters of lactating goats. Small Ruminant Research 56,165-171.

SAS (1998). SAS user's Guide for personal computers, SAS Institute Inc., Cary, SA, USA.

Sauerwein, H., B.H. Breier, B.W. Gallaher, C. Gotz, G. Kufner, T. Montag, M. Vickers and E. Schallenberger, 2000. Growth hormone treatment of breeding bulls used for artificial insemination improves fertilization rates. Domestic Animal Endocrinology. 18, 145-158. 
Schallenberger, E., G. Kufner, T.Montag and W. Lorrman, 1993. Does bovine somatotropin improve the performance of AI bulls? (Bibliographic Citation): Tierzuchter. 45: 1, 20-23. (Abstract).

Scheletter, G. and E. Nussel. (1975). Arbeitsmed Sozialmed Pracentimed. 10:25.

Stein EA., 1986. In Textbook of Clinical Chemistry, NW Tietz, ed. W.B. Saunders, Philadelphia, pp.879-886, 1818, 1829.

Taha, T.A., E.I. Abdel-Gawad and M. A. Ayoub, 2000. Monthly variations in some reproductive parameters of Barki and Awassi rams throughout 1 year under subtropical conditions 2.Biochemical and enzymatic properties of seminal plasma. Animal Sci., 71:325-332.

Zollner, N. and K. Kirsch, 1962. [Ueber die quantative bestimung von lipoiden (mikromethod) mittels der vielen naturlichel lipoiden (allen bekannten plasmalipoiden) gemeisamen sulphophospho-vanillin reaction]. Z. ges. exp.Med.135: 545-561. 
تأثير الحقن بهرمون النمو البقرى المخلق وراثياً قبل البلوغ على خصائص السائل المنوى

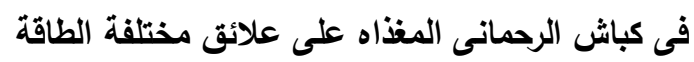

\author{
ياسين محمد حافظ' ، وليد شقوير" ، ابراهيم عوض الله" ، حمدى محمد مراد' \\ 1 - قسم الاتتاج الحيواتس، كلية النزاعة، جامعة القاهرة، الجيزة، ج.م.ع.، r - قسم الإنتاج الحيوانس، المركز \\ القومى للبحوث، الدقى ، جيزة، ج.م.ع.
}

أستهدف البحث دراسة تأثير الحقن قبل البلوغ بهرمون النمو البقرى الدخلق وراثيا على الخصائص الطبيعية

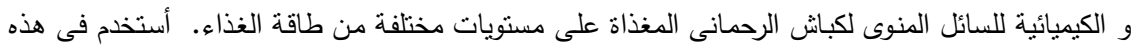

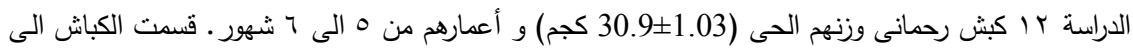

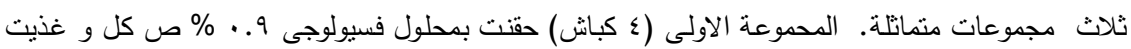

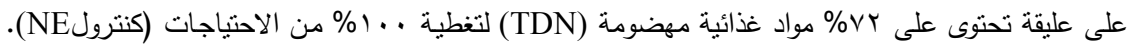

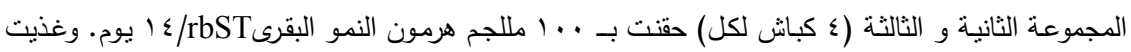

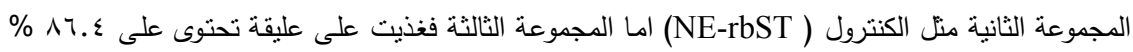

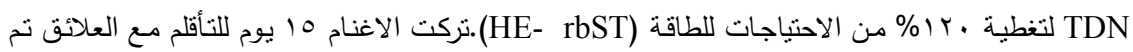

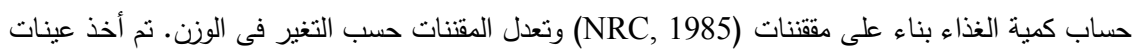

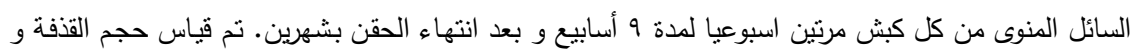

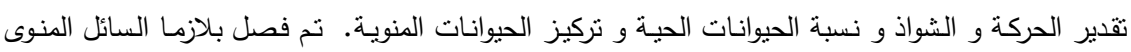
بالطرد المركزى و خزنت على - - r درجة مئوية.

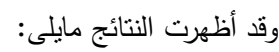
زاد حجم القففة معنويا فى مجموعة (NE- rbST) مقارنة بباقى المجموعات. ولم يختلف حجم القذفة

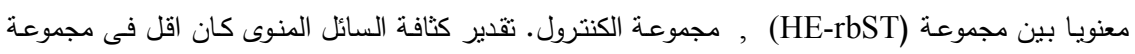

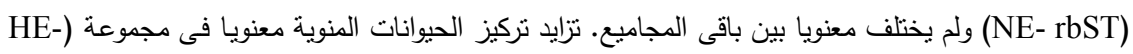

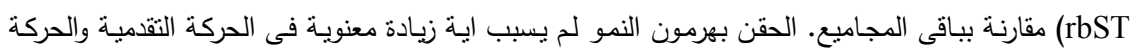
الجماعية ونسبة الحى و الميت و نسبة الحى والثواذ و تركيز الحيوانات المنوية بالقذفة.

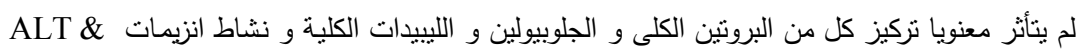

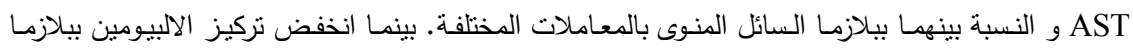

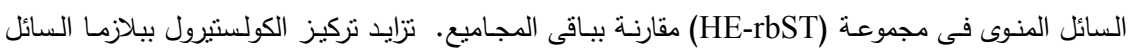
المنوى لكباش مجموعة (HE-rbST) مقارنة بالكنترول.

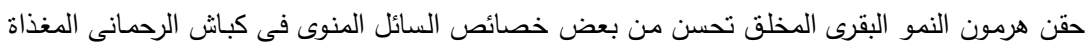

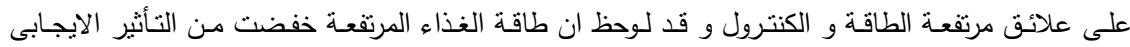

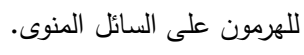

